\title{
USING GENRE TO DESCRIBE THE PROGRESSION OF HISTORICAL THINKING IN SCHOOL HISTORY TEXTBOOKS
}

\author{
DOI: http://dx.doi.org/10.17159/2223-0386/2015/n14a4
}

Pranitha Bharath

School of Education

University of KwaZulu-Natal

pranithasewlall@gmail.com

\author{
Carol Bertram \\ School of Education \\ University of KwaZulu-Natal \\ BertramC@ukzn.ac.za
}

\section{Abstract}

The focus of this paper is to describe how progression in historical thinking manifests across seven South African textbooks, one each from Grade 3 to Grade 9. This paper argues that one way in which progression in historical thinking is signalled in textbooks is by the genre type of the texts with which learners are required to engage. Our starting premise is that the development of historical thinking requires both substantive and procedural knowledge, or both first order and second order historical concepts. This paper presents only the genre analysis of a broader study which is informed by a combination of concepts from the fields of history education, sociology of knowledge and the genre approach of Systematic Functional Linguistics. The findings indicate that in terms of the texts that learners must read, there is a clear movement from the recording genre to the explaining genre and then to the interpretation genre across the seven books. The complexity of the substantive knowledge also increases as it moves from local contextualised knowledge to knowledge that is removed from the learner's context in both geography and time (decontextualized knowledge). In terms of writing demands, it is only in Grade 6 that learners commence writing explanations and thus engaging with the concept of cause and effect. It is only in Grade 9 that learners are expected to engage with writing multi-perspectives or to interpret and argue for a particular perspective as they are introduced to a range of different sources. This paper argues that using genre as a methodological tool can illuminate some aspects of progression of both first order and second order concepts in history.

Keywords: South Africa; History textbooks; Progression; Historical thinking; Genre; History Curriculum. 


\section{Introduction}

The purpose of this paper is to show how progression in historical thinking is reflected in a range of seven history textbooks, from Grade 3 to Grade 7, using methodological tools provided by a genre approach. School subjects such as mathematics and the natural sciences generally show progression through the grades by the learning of more complex and abstract concepts which are built up sequentially. The school subject of history finds progression both through the development of much more semantically dense substantive knowledge as well as through procedural knowledge, or what is termed "historical thinking". The substantive knowledge and procedural knowledge of school history is presented and assessed through language, thereby making language the key challenge to learner progression in history, because the language of history becomes increasingly complex and abstract as learners experience the grades (Schlepeggrell et al., 2012). In this paper we argue that (for this sample of seven textbooks) progression across the grades can be seen in the type of texts that learners must read and produce as evaluation tasks, as well as in the shift from local to unfamiliar contexts, and from contextualised to decontextualised knowledge.

The context for the study is post-apartheid South Africa and the object under study is a sample of history textbooks that carry the official history curriculum into the classroom. In this paper we first provide an overview of the South African history curriculum, provide a brief review of textbook analysis studies and describe the external language of description that was used to analyse a section of each text book. We then present the findings of the analysis of the seven textbooks, and show how using genre as a methodological tool enables us to describe the progression of some aspects of historical thinking.

\section{Changes in the South African history curriculum}

It was clear that the history school curriculum would need substantial reform in the post-apartheid era, as the subject had been used to promote Afrikaner nationalism (Dean, 1983; Du Preez, 1983). The first curriculum reform (launched in 1998) was called Curriculum 2005. It combined history with geography in the primary school (Grades R-9) and stripped history of specific content that needed to be taught (Seleti, 1997). The curriculum provided teachers only with a set of learning outcomes which learners could ostensibly meet using any content chosen by the teacher. A review of this 
radical outcomes-based curriculum noted that the curriculum needed greater structure. As a result, the Revised National Curriculum Statements separated history from geography within the learning area of Social Science and provided each subject with its own list of content, outcomes and assessment standards (Chisholm, 2005).

A third iteration of the national curriculum is currently used in schools: the National Curriculum Statement Grades R-12, Curriculum and Assessment Policy Statement (CAPS). The CAPS for Social Sciences (Department of Basic Education, 2011) is informed by the principles of social transformation, active and critical thinking, high knowledge and high skill as well as progression. From Grade 4 to Grade 9, history is taught alongside geography in the subject of Social Sciences. The main change is that the curriculum is no longer organised around outcomes and assessment standards.

The post-apartheid curriculum also made a shift away from the "great tradition" where school history focused only on what happened in the past to an "alternative tradition" which emphasises the importance of learners "doing" history. This was influenced by the constructivist model of history which focused on historical skills in Britain in the 1970s (Shemilt, 1980). The vision of the official curriculum is that learners should be taught to embrace historical ways of thinking and sources had to be used in specialised ways so as to develop learner skills of inquiry and critical thinking (Bertram, 2008b). According to the CAPS Social Sciences document (DBE, 2011:11) the concepts in history are historical sources and evidence, the multi-perspective approach, causeand-effect, change and continuity, time and chronology. These concepts bear a strong semblance to the historical thinking benchmarks described by Seixas (2006) and the second-order concepts described by Lee and Ashby (2001). The change from memory-history to disciplinary history (Lévesque, 2008) has impacted on school history, in that the curriculum requires a focus on the procedures of the discipline as well as replacing nationalistic Afrikaner history and heroes from the apartheid era with the stories of the democratic era and its new heroes.

\section{Textbook studies}

Since "school textbooks are the dominant definition of the curriculum in schools" (Crawford, 2003:3), they are seen to play an extensive role in the South African classroom (Report on History and Archaeology, 2000; 
Chisholm, 2013). LaSpina (1981:1) maintains that "History textbooks seem to occupy a place in education that is similar to traditional religious sacred books, transmitting our past and cultural heritage" and this has not changed much in most South African classrooms, regardless of technological advancement, e-learning and internet access in some schools.

In South Africa the vast majority of studies about textbooks are engaged in exploring the nature of the substantive knowledge that is presented in them. Textbooks prescribed before democracy in 1994 propagated the ideals of the apartheid government (Chisholm, 2008). The shape and content of history is inexorably tied to those who were in power. Many studies have focused on areas such as prejudice and in writing a new history for South Africa (Bam \& Visser, 1996), concept representation (Matoti, 1990; Ranchod, 2001), national narratives (Van Eeden, 2008, 2010), ideology and citizenship (Chisholm, 1981, 2008). There are some studies that have focused on curriculum and knowledge (Bertram, 2008a; Bharath, 2009; Bertram \& Bharath, 2011; Firth, 2013), historical consciousness (Van Jaarsveld, 1989; Kwang-Su, 1999; Beek, 2001; Mazabow, 2003) and historical literacy (Wasserman, 2008; Maposa \& Wasserman, 2009; Waller, 2009).

A diverse bank of international literature that is also available at the Georg Eckert Institute for Textbook Research in Braunschweig, Germany, ranges from analysing teaching practices using printed textbooks in Argentinian Elementary Schools (Romero, 2014) to historiographical work in Chilean textbooks (Minte, 2014). However, there are few studies that focus on how textbooks show progression in historical thinking.

\section{Knowledge structures and progression in school history}

This paper does not engage with the discourses of bias, prejudice or stereotyping in the substantive history that is represented in South African textbooks, but focuses on the ways in which progression in historical thinking can be tracked though the genre of texts. The study is broadly informed by the field of sociology of knowledge and knowledge structures.

The theoretical starting point is the distinction that Bernstein (1971) makes between everyday knowledge and school knowledge. He classified school knowledge as "formal and specialised" while everyday knowledge was more personal and localised where the context of the home plays a significant role in developing what the learner knows before they come to school. According 
to Bernstein (1999), school knowledge (academic) is categorised as a vertical discourse and everyday knowledge is categorised as a horizontal discourse. These discourses are differently structured and thus acquired differently.

The vertical discourse described by Bernstein has the capacity to produce knowledge at increasingly higher levels of abstraction, generality and integration and hence are able to produce progression in knowledge (Moore, 2008). Within vertical discourses, school subjects may have a horizontal or a vertical knowledge structure. Martin (2008) maintains that both school history and English have horizontal knowledge structures while the sciences possess a hierarchical knowledge structure. Vertical knowledge structures such as the physical and biological sciences find progression in clearly sequenced knowledge and make clear moves from the concrete to progressively more abstract concepts. Theory develops through integration, towards more integrative and general propositions. On the other hand, progression in horizontal knowledge structures occurs not through more integrated and generalisable theory (Muller, 2008) but rather through the introduction of new languages which construct a new perspective, new questions and new connections. Because these languages are incommensurable, they defy incorporation at the level of integration and thus knowledge progression does not happen by developing more general propositions (Muller, 2008). If this is the case, then the critical question is "how does history as a horizontal knowledge structure build progression or verticality"?

When describing the process of progression, it is useful to use the distinction of substantive and procedural knowledge. Since the structure of the discipline of history or the nature of historical knowledge is said to be composed of two inter-twined strands which are the process and content dimensions (Dean, 2004), progression would mean the advancement of both. Procedural knowledge is the "know how", the methodology of historians or the procedures for conducting historical investigations and the substantive knowledge is the "know that", the statements of fact or concepts of history. To be inducted into the discipline and to develop ways of thinking historically requires the acquisition of both (Bertram, 2008b, 2012).

Substantive history knowledge can be sequenced in a range of different ways, with chronology of events being the most common. Regarding substantive knowledge, the concepts of contextualised and decontextualised knowledge are useful principles for working with progression in history. The principle is one of starting in the lower grades with narratives that are concrete and 
embedded in learners' lives rather than concepts that are abstract and often ideological. It would mean starting with history content that is close to the learners' everyday world, such as their family history or the history of the local community where they live. These progression principles reflect the learning theories that suggest that learning involves moving from concrete to abstract concepts, from local to more universal knowledge.

History as a horizontal knowledge structure also finds progression in the development of procedural knowledge. Lee $\&$ Shemilt (2003) advocate that "progression" came to focus on the way in which pupils' ideas about history and the past develop, that is "historical thinking". Hence Lee \& Ashby (2000) argue that the acquisition of more powerful procedural or second-order ideas is perhaps the best way of giving sense to the notion of progression in history.

Seixas (2006) describes historical thinking as having six structural and procedural benchmarks which are: to establish historical significance, use primary source evidence, identify continuity and change, analyse cause and consequence, take historical perspectives and understand the moral dimension of historical interpretation. According to Van Drie \& Boxtel (2008:88), scholars have linked historical thinking and reasoning to historical consciousness or literacy (e.g. Seixas, 1993; Spoehr and Spoehr, 1994; Husbands, 1996; VanSledright \& Frankes, 2000; Wineburg, 2001; Schreiber et al., 2006). The progression-model advanced by Ford (2014) in the United Kingdom moves away from a linear way of thinking about progression and uses an approach of non-linear conceptual mastery, again focusing on the second-order concepts.

"Progression" is not movement on a linear scale of reasoning from lowerorder thinking to higher-order thinking. Lévesque (2008) argues that "progression" in historical thinking is simultaneous "within each" domain of knowledge and not from one to another. Sophisticated historical thinkers are not those who have successfully moved from content acquisition to mastery of procedural knowledge but those who have made significant progress in understanding both the substance of the past and the procedures and secondorder concepts necessary to make sense of it. This study aims to make visible how the substantive and procedural concepts of history knowledge shift across the grades, and signal progression in the seven sampled textbooks. 


\section{Conceptual framework for the study}

This paper reports on how the seven textbooks under study develop progression, using the conceptual lens of genre and language. The study analyses the genre of texts which learners must read, and the genre of the texts which learners must produce, using an analysis tool which is shown in Table 1.

Theories from history education and descriptions of historical concepts (Shemilt, 1976; Lee \& Ashby, 2001; Lévesque, 2008), the sociology of knowledge structures (Bernstein, 1996) and Systemic Functional Linguistics, language and genre approaches (Coffin 2006; Martin, 2013) were integrated to develop a conceptual frame of the broader study. ${ }^{1}$

Coffin (2006c) distinguishes between the language demands of school which are specialised and academic when compared to the language of everyday life, which is spontaneous and context-bound. The language of texts, called academic language, presents information in new ways, using vocabulary, grammar and text structures that call for advanced proficiency in this complex language (Schlepegrell, Greer \&Taylor, 2008).

Martin (2013) views these technicalities and abstractions in subject-specific discourses in relation to high-stakes reading and writing. He describes the transition from primary to secondary phases of schooling as a shift from basic literacy to subject-based learning which is composed of specialised discourse. This in turn has impacted genre-based literacy programmes aimed at mastering writing for different purposes (e.g., recount, narrative, report, procedure, explanation, exposition) (Martin, 2013). Derewianka (2003) contends that genre-based teaching is very influential as genres are opportunities to teach grammatical structures in context.

Coffin (2006c) maintains that history, like other school subjects has a specific language and that each piece of writing in history has a distinct purpose relating to wider disciplinary practices, which she labels as "genre". She indicates that Systemic Functional Linguistics (SFL) is an area in which linguists have developed tools to analyse how language functions as the means through which knowledge and skill are transmitted. Disciplinary knowledge is re-contextualised for school use and that the disciplinary purposes are played out in language via the texts students are required to read and write (Coffin, 2006c).

1 Bharath's forthcoming PhD study entitled: An investigation of progression into historical thinking in South African History textbooks. 
Building on Coffin's ideas, Schleppegrell (2012) explains how a narrative uses different kinds of grammatical resources as the text unfolds which are more active doing processes in the main part of the story and more reflective being and sensing processes in the final evaluative stage. The focus of the SFL lens on a narrative text allows teachers to identify how grammar functions to make different kinds of meaning at different points in a text. Apart from grammar patterns signalling progression, Fang \& Schleppegrell (2010) argue that school knowledge reflected in the language transmitting it, becomes increasingly abstract, dense and complex. Textbooks used in earlier years are described as non-technical and involved simple clauses which could be read with ease while texts engaged with in later years tend to present technical, abstract vocabulary with dense, compacted information. Autobiographical recounts in school history are normally written in the first year of schooling (or indeed primary schooling) and as a result, they have a relatively simple style. The lexical density (i.e. the number of lexical items per clause) is often low for written language in the early grades (Coffin, 2006a).

The historical genres are mainly divided into two groups: the "chronological" group consists of recounts, empathetic autobiographies, biographical recounts and historical recounts, as well as accounts, while the "non-chronological" genres consist of site and period studies (Derewianka \& Jones, 2012). In addition, students at a certain level of maturity start using diversified ways to realise attitudinal lexis and grammatical metaphor. They exploit processes which become diverse and specialised. According to Greer (1988, cited in Schleppegrell, 2012), it is through writing that we learn to think and make meaning and that writing has specific characteristics relevant to the subject. Thus, in relation to history, writing needs to reflect the disciplinary thinking of constructing arguments and reaching conclusions through the use of evidence, critical thinking, and a detailed analysis of the context and origin of the evidence.

For this study, Martin's exemplars are merged and reworked with Coffin's terminology into a single analysis tool (represented in Table 1) which is used to identify and classify genre in the textbooks. Martin (2007) argues that the principle of learners reading and engaging with a set of genres in school stimulates textured and structured writing production. He presents two useful exemplars to classify genres. The first shows how history as a set of genres is ordered, carving a learning pathway. It commences with genres similar to those that students are familiar with in the oral culture outside the school and moving on through those particular to history, including various chronicling genres 
moving on to argumentation genres. The second arrangement of genres, drawn from Coffin (1997, 2000); Martin (2002); Martin \& Wodak (2004); Martin $\&$ Rose (2005) is represented on a vertical topological vector running from common to uncommon sense. Table 1 represents the combination of these ideas.

\section{Table 1: Genre types in school history}

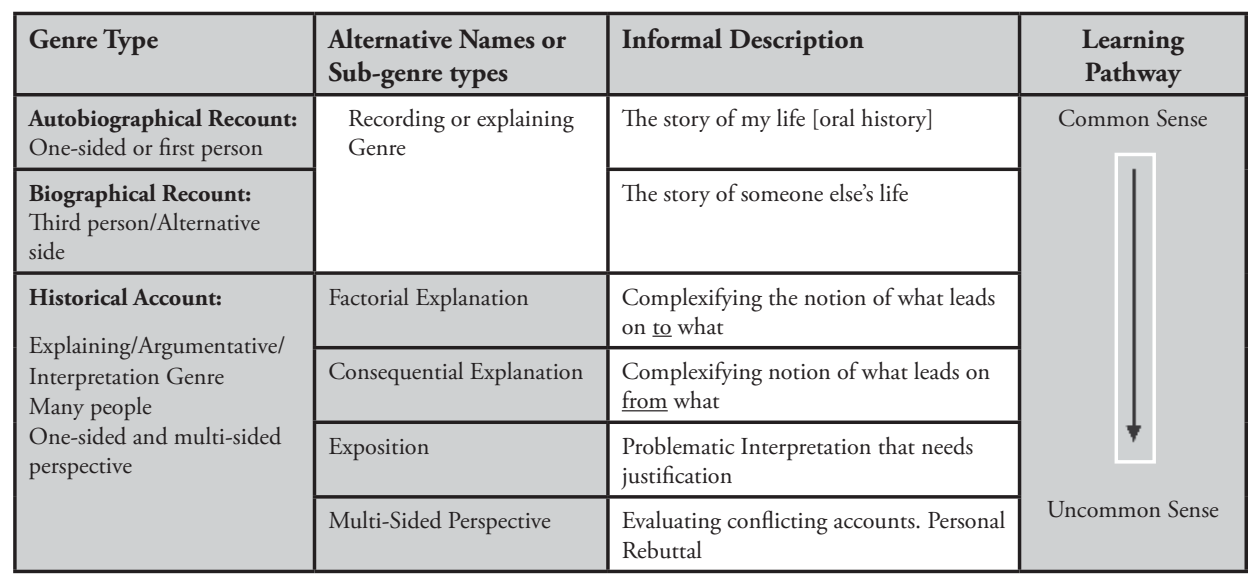

Source: Martin, 2007 \& Coffin, 2006c

\section{Research design and methodology}

The methodology is that of content analysis, using qualitative analysis to understand how historical knowledge in textbooks signals progression. Data was generated through different categories, and this study reports on the analysis of two key aspects, namely the genre type of the reading texts and the genre type of the writing tasks that learners are required to do.

Since it was not possible to analyse the entire textbook, a selection of one chapter from each book was made. These are the topics on the history of a South African past, from its early inhabitants to democracy.

\section{Table 2: The titles of the chapters that were analysed in each textbook}

\begin{tabular}{|l|c|c|}
\hline TOPIC & GRADE & BOOK \\
\hline 1. About me and how people lived long ago & 3 & A \\
\hline 2. Local History & 4 & B \\
\hline 3. Hunter-Gatherers and Herders in South Africa & 5 & C \\
\hline 4. An African Kingdom long ago in Southern Africa's Mapungubwe & 6 & D \\
\hline 5. The Colonisation of the Cape in the 17th and 18th centuries & 7 & E \\
\hline
\end{tabular}




\begin{tabular}{|l|c|c|}
\hline 6. The Mineral Revolution in South Africa & 8 & F \\
\hline 7. Turning points in South African history $1960,1976,1994$ & 9 & G \\
\hline
\end{tabular}

There are minimal ethical considerations due to the fact that textbooks are readily available documents which are already in the public domain. The national Department of Education in South Africa selects a range of textbooks from those submitted by publishers to appear on the list of approved textbooks. Teachers may choose any textbook from this list. The official policy on textbooks is that every learner should have a textbook paid for by the Department of Basic Education. The seven books in the study sample are purposively selected as those which are popular choices at various primary and secondary schools in Pietermaritzburg, KwaZulu-Natal. The popularity of the books was established by the first author's attendance at teacher development workshops, meetings and networking.

\section{Findings and discussion}

\section{Text genres in the seven History textbooks}

There is clear movement from the recording genre to the explaining genre and then to the interpretation genre (Coffin, 2006a) across the seven books. In earlier grades, there is the absence of a chronological framework and the structure of the information in the textbook is fairly everyday (common sense). There is no historical event description but the focus is on personal event description. There are more generalised participant descriptions in lower grades which advance to more detailed biographies of specialised participants like Nelson Mandela (Grade 9) and Pius Langa (Grade 6). The Grades 6, 7, 8 and 9 books take on a purposive chronological sequence in historical events. This is an abridged version of events merely highlighting the beginning, middle and end of the event. Grade 9 progresses to include effects of the event in greater detail.

The number of events under study increases and these are studied from various perspectives. The number of people involved in the events also increases, therefore both general and specific participants in the events are scrutinised. The Grade 9 text has various sources ranging from extracts from books, autobiographies, speeches, interviews with eye-witnesses to events to deliver this multi-perspective approach. The learners have to read and draw conclusions about the authenticity and bias of the sources and construct 
their own narratives. Through interacting with a variety of texts, learners also extend their use of vocabulary.

The reading demands of the learner in the earlier grades are to understand their immediate context in their present lives (Grade 3) then progresses to the local history of their environment in Grade 4. Image 1 below shows how Grade 3 learners are presented with a timeline of the life of a boy named Rishon. The time-line is used to show a Grade 3 learner how one's personal experiences and milestones may constitute a story about a person's early life and history. It integrates the autobiographical and biographical recount as the experiences of Rishon and these are paralleled with the learner's own milestones, showing its relevance. The time-line in history is used to chronicle one's own life experiences. The learner is not required to produce any written work. The text is intended as oral discussion.

Image 1: A timeline for Grade 3 learners

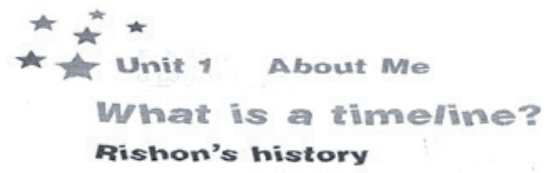

Rishon's history

A timeline enables you to see important information about your past life, to recognise achievements you have made and helps you plan what you would like to do in the future.

Read the story of Rishon's history.

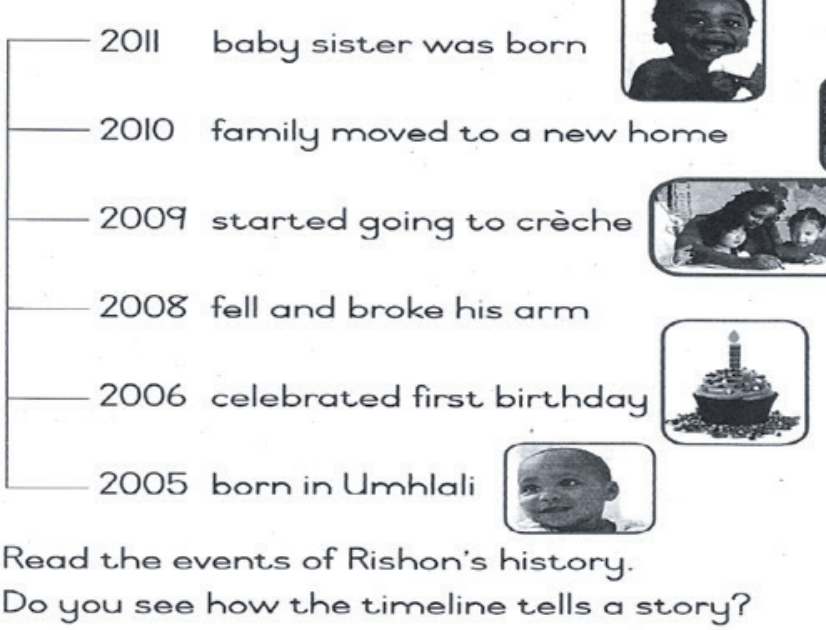

Source: Scanned from Book A, Grade 3 Learner's Book, p. 1. 
Grade 3 learners interrogate colourful, everyday pictures of families and people and are also introduced to black-and-white photographs to show them how "historical" images first appeared. As reading advances to Grade 4, learners read about how stories can be constructed by gathering information from objects in the environment (evidence). They are shown how visual, written and oral elements obtained from magazines, newspapers, interviewing people etc. can be used to glean information. In Grade 5, learners read about the San people by studying pictures of the San and drawings of archaeological findings that enable them to construct history knowledge on the San. The example in Image 2 from the Grade 7 text represents an historical account, more specifically the sub-genre of consequential explanation. This section deals with the slave trade and the resistance movements which grew out of the slave experience. A firm portrayal of cause-and-consequence is seen against the background of serious revolts. The chapter initially presents the origins and background of the Transatlantic Slave Trade as a historical account and is also structured to present the causes and effects of the slave trade, culminating in emancipation with reference to laws at that time.

Image 2: An historical account for Grade 7 learners that deals with the slave trade and the resistance movement

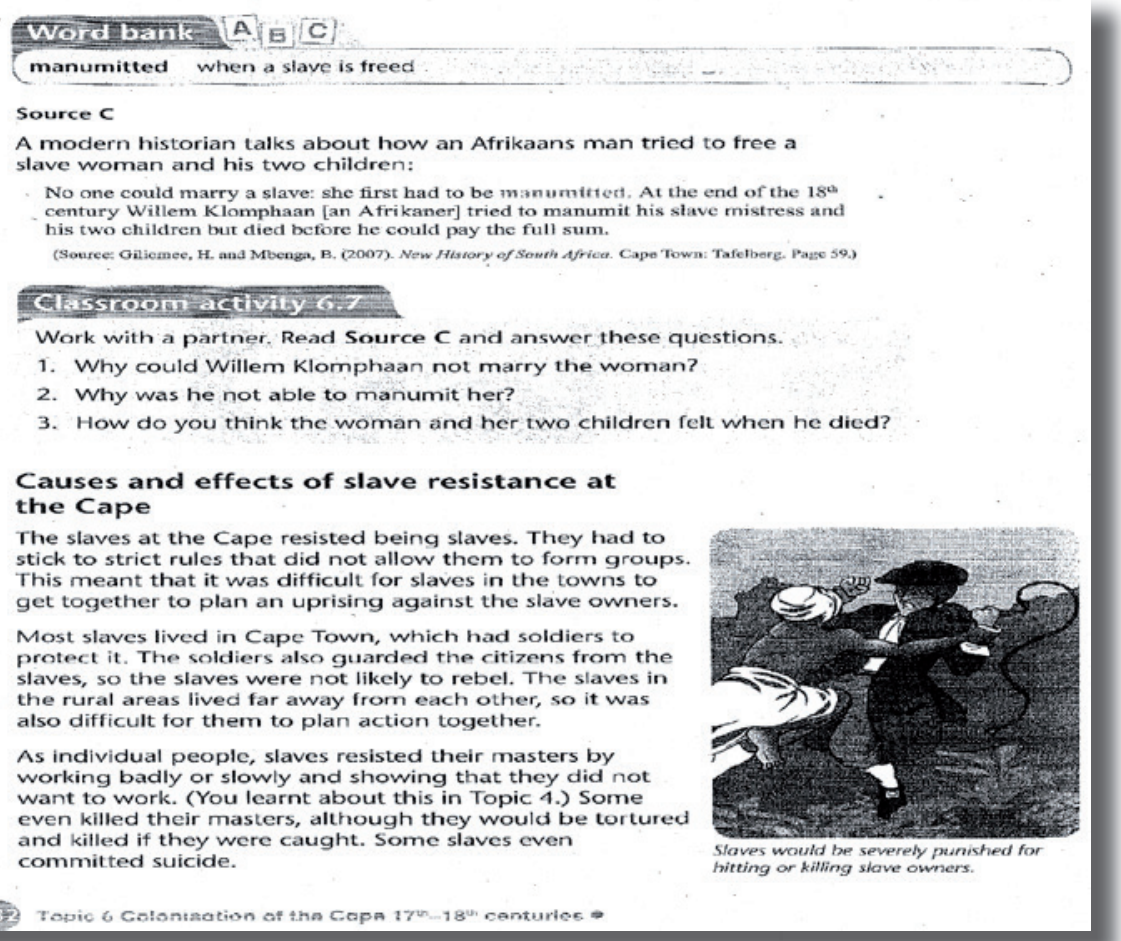

Source: Scanned from Book E, Grade 7 Learner’s Book, p. 132. 
Reading demands become more intensive in Grade 8 with the introduction of diagrams and political cartoons which require greater analysis, explanation and interpretation. Time-lines advance to include additional information across larger time periods about events out of the learners' context (decontextualisation). The number of photographs and posters for reading and analysis increase which require an informed critical reader. At Grade 9 level, there are extracts from autobiographies, interviews and speeches which require that a learner be proficient in reading in order to engage with highlevel tasks. The tasks have to be read and require learners to be able to read at advanced levels so as to undertake study of the background of events such as the Sharpeville massacre, Soweto uprising and the circumstances at Langa, Evaton and Vanderbijlpark. The reading here takes the learner into an entirely new context with a number of integrating events. Temporal and spatial advancement presents decontextualisation. It is clear that the language moves from informal everyday language to one where the language competence is advanced which is more "academic" in nature. This progression shows that knowledge advances from common-sense knowledge (immediate) to uncommon-sense knowledge (decontextualised) across the grades (Bernstein, 1975).

Table 3 below demonstrates how the genre of the texts that must be read increases in the complexity of the substantive knowledge, which moves from local knowledge to knowledge that is removed from the learner's context in both geography and time.

\section{Table 3: Summary of the reading demands made on learners according to genre type}

\begin{tabular}{|c|c|c|c|c|c|c|}
\hline Grade 3 & Grade 4 & Grade 5 & Grade 6 & Grade 7 & Grade 8 & Grade 9 \\
\hline $\begin{array}{l}\text {-Time-line of } \\
\text { Rishon's history. } \\
\text {-Describing } \\
\text { photos of present } \\
\text { and past. } \\
\text {-Extract on a } \\
\text { painting and its } \\
\text { representation of } \\
\text { the past forms of } \\
\text { transport. }\end{array}$ & $\begin{array}{l}\text {-Pictures, } \\
\text { hotographs and } \\
\text { paragraphs of } \\
\text { information } \\
\text { on how local } \\
\text { history is } \\
\text { constructed. }\end{array}$ & $\begin{array}{l}\text {-Pictures, } \\
\text { snippets of } \\
\text { information } \\
\text { on San } \\
\text { lifestyle, social } \\
\text { organisation, } \\
\text { beliefs and } \\
\text { religion, how } \\
\text { local history } \\
\text { is constructed } \\
\text { from objects } \\
\text { belonging to } \\
\text { San. }\end{array}$ & $\begin{array}{l}\text {-Early } \\
\text { settlements in } \\
\text { the Limpopo } \\
\text { Valley. } \\
\text {-Maps, pictures, } \\
\text { drawings and } \\
\text { information } \\
\text { about early } \\
\text { African } \\
\text { societies and } \\
\text { development of } \\
\text { trade. } \\
\text {-Appearance } \\
\text { of event } \\
\text { description and } \\
\text { chronology }\end{array}$ & $\begin{array}{l}\text {-Location of } \\
\text { indigenous } \\
\text { inhabitants of the } \\
\text { Cape in the } 17^{\text {th }} \\
\text { century } \\
\text {-Colonisation } \\
\text { and dispossession } \\
\text {-Protracted } \\
\text { struggle and } \\
\text { clashes for land } \\
\text { and cattle. } \\
\text {-Summarised } \\
\text { chronological } \\
\text { events. }\end{array}$ & $\begin{array}{l}\text {-Maps, } \\
\text { photographs, } \\
\text { pictures, } \\
\text { painting, } \\
\text { diagrams, } \\
\text { cartoons, } \\
\text { time-lines, } \\
\text { and sources } \\
\text { of interviews, } \\
\text { posters, mind- } \\
\text { maps, } \\
\\
\text {-Abridged } \\
\text { version of the } \\
\text { chronological } \\
\text { events that led } \\
\text { to the Mineral } \\
\text { Revolution in } \\
\text { South Africa. }\end{array}$ & $\begin{array}{l}\text {-Event } \\
\text { chronological } \\
\text { dismantling. } \\
\text {-Background and } \\
\text { events: Sharpeville } \\
\text { massacre, } \\
\text { Soweto uprising, } \\
\text { Langa, Evaton, } \\
\text { Vanderbijlpark, } \\
\text { Black } \\
\text { Consciousness } \\
\\
\text {-Sources: books, } \\
\text { autobiography, } \\
\text { interviews, } \\
\text { speeches, time- } \\
\text { lines on the event } \\
\text { cartoons, posters. }\end{array}$ \\
\hline
\end{tabular}


Table 4 below summarises the genre type across the seven textbooks, showing clearly the move from a recording genre to explaining to interpretation and argument. In terms of chronology, there is no mention of this in the Grade 3, 4 and 5 textbooks, and a chronological framework only becomes clear in the Grade 6 textbook. Similarly narrative texts and detailed description of specific historical events only start appearing in the Grade 6 textbook. It seems that learners in Grade 3, 4 and 5 are hardly being inducted into the key concepts of history such as narrative, chronology and specific historical events.

\section{Table 4: Summary of genre types across Grades 3-9 textbooks}

\begin{tabular}{|c|c|c|c|c|c|c|c|}
\hline & Grade 3 & Grade 4 & Grade 5 & Grade 6 & Grade 7 & Grade 8 & Grade 9 \\
\hline Genre & $\begin{array}{l}\text { Recording. } \\
\text { Autobiographi- } \\
\text { cal personal } \\
\text { recount. }\end{array}$ & Recording & $\begin{array}{l}\text { Move from } \\
\text { recording to } \\
\text { explaining } \\
\text { genre. }\end{array}$ & $\begin{array}{l}\text { Move from } \\
\text { recording to } \\
\text { explaining } \\
\text { genre. }\end{array}$ & $\begin{array}{l}\text { Move from } \\
\text { recording } \\
\text { to } \\
\text { explaining } \\
\text { genre. }\end{array}$ & $\begin{array}{l}\text { Move from } \\
\text { explaining } \\
\text { genre to } \\
\text { interpreta- } \\
\text { tion. }\end{array}$ & $\begin{array}{l}\text { Move from } \\
\text { explaining } \\
\text { genre to } \\
\text { interpreta- } \\
\text { tion and } \\
\text { argument. }\end{array}$ \\
\hline Chronology & $\begin{array}{l}\text { Absence of } \\
\text { chronological } \\
\text { framework }\end{array}$ & $\begin{array}{l}\text { Absence of } \\
\text { chronolo- } \\
\text { gical } \\
\text { framework }\end{array}$ & $\begin{array}{l}\text { Absence of } \\
\text { chronological } \\
\text { framework. }\end{array}$ & $\begin{array}{l}\text { Advent of } \\
\text { purposive } \\
\text { chronology }\end{array}$ & $\begin{array}{l}\text { Purposive } \\
\text { chronology }\end{array}$ & $\begin{array}{l}\text { Purposive } \\
\text { chronological } \\
\text { discussion of } \\
\text { gold mining }\end{array}$ & $\begin{array}{l}\text { Purposive } \\
\text { chronolo- } \\
\text { gical/ } \\
\text { sequenced } \\
\text { event } \\
\text { description. }\end{array}$ \\
\hline Narrative & $\begin{array}{l}\text { No narrative } \\
\text { text }\end{array}$ & $\begin{array}{l}\text { Absence of } \\
\text { narrative } \\
\text { text } \\
\text { structure } \\
\text { (no } \\
\text { beginning, } \\
\text { middle or } \\
\text { end). }\end{array}$ & $\begin{array}{l}\text { Absence of } \\
\text { narrative text } \\
\text { structure } \\
\text { (no } \\
\text { beginning, } \\
\text { middle or } \\
\text { end). }\end{array}$ & $\begin{array}{l}\text { Appearance } \\
\text { of narrative } \\
\text { text } \\
\text { structure: } \\
\text { beginning, } \\
\text { middle } \\
\text { or end of } \\
\text { traditional } \\
\text { societies). }\end{array}$ & $\begin{array}{l}\text { Clear } \\
\text { narrative } \\
\text { text } \\
\text { structure } \\
\text { beginning, } \\
\text { middle or } \\
\text { end). }\end{array}$ & $\begin{array}{l}\text { Clear } \\
\text { narrative text } \\
\text { structure: } \\
\text { beginning } \\
\text { (background), } \\
\text { middle or } \\
\text { end. }\end{array}$ & $\begin{array}{l}\text { Clear narra- } \\
\text { tive text } \\
\text { structure: } \\
\text { beginning } \\
\text { (back- } \\
\text { ground), } \\
\text { middle or } \\
\text { end. }\end{array}$ \\
\hline $\begin{array}{l}\text { Nature of } \\
\text { participants }\end{array}$ & Personal & $\begin{array}{l}\text { Remote } \\
\text { generalised } \\
\text { partici- } \\
\text { pants. }\end{array}$ & $\begin{array}{l}\text { Remote } \\
\text { generalised } \\
\text { participants: } \\
\text { San. }\end{array}$ & $\begin{array}{l}\text { Specific } \\
\text { partici- } \\
\text { pants: King, } \\
\text { Chief, } \\
\text { Marco } \\
\text { Polo, } \\
\text { Mandela, } \\
\text { Thabo } \\
\text { Mbeki }\end{array}$ & $\begin{array}{l}\text { Specific } \\
\text { partici- } \\
\text { pants: } \\
\text { Galant, } \\
\text { Wilhelm } \\
\text { Bleek } \\
\text { generali- } \\
\text { sed } \\
\text { articipants: } \\
\text { Khoi-khoi, } \\
\text { settlers }\end{array}$ & $\begin{array}{l}\text { Specific } \\
\text { participants: } \\
\text { Mahadu } \\
\text { Nkadimeng } \\
\text { Generalised } \\
\text { participants: } \\
\text { miners, } \\
\text { migrant } \\
\text { workers. }\end{array}$ & $\begin{array}{l}\text { Specific } \\
\text { participants: } \\
\text { Steve Biko, } \\
\text { Nelson } \\
\text { Mandela, } \\
\text { Phillip } \\
\text { Kgosana, } \\
\text { Tsitsi } \\
\text { Mashinini, } \\
\text { Generalised } \\
\text { participants: } \\
\text { ANC, PAC, } \\
\text { Cosatu, } \\
\text { Black } \\
\text { people, } \\
\text { white } \\
\text { people, and } \\
\text { freedom } \\
\text { fighters. }\end{array}$ \\
\hline
\end{tabular}




\begin{tabular}{|l|l|l|l|l|l|l|l|}
\hline $\begin{array}{l}\text { Event } \\
\text { description }\end{array}$ & $\begin{array}{l}\text { Absence } \\
\text { of event } \\
\text { description. }\end{array}$ & $\begin{array}{l}\text { Absence } \\
\text { of event } \\
\text { descrip- } \\
\text { tion. }\end{array}$ & $\begin{array}{l}\text { Absence } \\
\text { of event } \\
\text { description }\end{array}$ & $\begin{array}{l}\text { Appearance } \\
\text { of event } \\
\text { description }\end{array}$ & $\begin{array}{l}\text { Clear event } \\
\text { description } \\
\text { (abridged, } \\
\text { summari- } \\
\text { sed) }\end{array}$ & $\begin{array}{l}\text { Clear } \\
\text { description of } \\
\text { many events } \\
\text { (abridged, } \\
\text { summarised) }\end{array}$ & $\begin{array}{l}\text { Clear } \\
\text { description } \\
\text { of many } \\
\text { events } \\
\text { (abridged, } \\
\text { summarised } \\
\text { and bulleted } \\
\text { for easy } \\
\text { reference } \\
\text { on turning } \\
\text { points) }\end{array}$ \\
\hline
\end{tabular}

It could be argued that interpretation and argumentative texts should be introduced earlier than Grade 9, as these are vital to developing an understanding of history from a range of different perspectives (multiperspectivity). Similarly it seems problematic that learners in Grade 3, 4 and 5 are in fact hardly being inducted into the key second order concepts of history such as narrative, chronology and specific historical events. It appears that it is only in Grade 6 that these concepts become explicit in the sampled textbooks.

\section{Writing expected in graded history textbooks}

This aspect of the analysis shows a clear pathway of development as learners in Grade 3 are not required to produce any writing, while in Grade 9 learners must produce extended writing in various genres. The activities in the earlier grades require more oral response and teacher-led engagement. Grade 4 learners are required to tabularise and list, after recognising objects that contribute to local history construction. They are also involved in drawing up questions for interviews and in recording observations of their visits to local buildings, historical sites, etc. These are very practical tasks which require simple sentence construction. Grade 5 learners are introduced to an aspect of the discipline of school history where they construct very simple but longer texts about the San lifestyle and practices by describing and listing archaeological findings and then relating the artefacts to how the San lived.

Grade 6 writing production involves greater details and complexity around map study and there is an increase in length of writing about exploration and trade. This is gauged from the type/level of the questions asked, which require detailed explanation. Shifts in context and understanding require more description and reasoning.

An example from a Grade 6 textbook, from a later chapter, requires learners to write a biographical recount. Learners are required to research and write the biography of either Fathima Meer or Pius Langa or any person who 
worked to build a democratic South Africa in a specially designed project format with clear headings constituting the "Early Life", "What they did to help build democracy in South Africa", "How their actions made a difference" and "What I learnt from their history". The requirements here clearly show a build-up of both substantive knowledge as well as procedural knowledge. The second-order concepts can be inferred from what the headings intend for the learner to acquire. The "Early Life" to "What they did to build democracy in South Africa" develops this idea of "continuity- and-change" while the "How their actions made a difference" develops understanding around "cause-andeffect" and this development is concluded with "What I learnt from their history" which is demonstrative of "historical-significance".

The Grade 7 textbook requires learners to write explanations and produce paragraphs on their understanding of "colonisation" and the "warfare between indigenous populations and the immigrants". The writing the Grade 7's produce is also the result of comparing different maps. These activities require understanding of different sub-components or elements such as rainfall patterns, climate, population distribution and temperature which influenced the lifestyle and location of the people in South Africa. These circumstances resulted in competition for land, resources and subsistence as people of that time produced their own food. The advanced and complex thinking in this particular written activity requires an understanding of a combination of factors which would denote a highly proficient learner whose ability must be aligned with task expectation.

Complexity in Grade 8 written tasks is far more intense as learners are required to create time-lines, posters and mind-maps which require understanding of the dimensions, content, style, criteria and structure of the text in order to produce it. Knowledge and understanding of the event must proceed before the learner tackles the task. Learners have to write definitions and explanations which involve comprehensive understanding of the background, changes to the economy, context and circumstances surrounding the Mineral Revolution. They have to provide reasons for and evaluate the circumstances of the event. Writing production required in Grade 9, in this sample of textbooks, is the most complex with learners required to write essays on the background, causes, results and effects of a particular event.

These analysed texts demonstrate progression in the genres by first engaging the autobiographical genre (Grade 3: my life history) to the biographical genre (Grade 6: Fatima Meer), to the background, context, causes and 
evaluation of the event of the Mineral Revolution (Grade 9). When academic disciplines are recontextualised as school subjects, Coffin (2006) argues that the disciplinary purposes are played out in language via the different types of texts students are required to read and write. She identifies important genres of recording, explaining and arguing in history to span the development phases of learners in history so that learners are able to sequence past events. The genres have distinct lexical and grammatical choices which allow learners to build a record of past events in order to develop a historical understanding of events. Learners are also required to produce mind-maps, present debates and posters on the topic in a very structured manner. These require time to plan, design and present. Increasing complexity is the overall trend of the advancing grades. The use of source analysis, bias detection and critical argument in the type of essays learners are required to write is in line with Greer's (1988:21) contention that writing in history, "needs to reflect the disciplinary thinking of constructing arguments and reaching conclusions through the use of evidence, critical thinking, and a detailed analysis of the context and origin of evidence" (cited in Schleppegrell et al., 2008).

Table 5 below summarises the findings and shows how there is an increase of writing demands from descriptions of events to explanations, which develops learners' understanding of cause and effect.

\section{Table 5: Summary of the writing demands made on learners according to genre type}

\begin{tabular}{|l|l|l|l|l|l|l|}
\hline Grade 3 & Grade 4 & Grade 5 & Grade 6 & Grade 7 & Grade 8 & Grade 9 \\
\hline $\begin{array}{l}\text { Does not } \\
\text { require any } \\
\text { written } \\
\text { activity. }\end{array}$ & $\begin{array}{l}\text { Tabling/listing } \\
\text { sources/ objects } \\
\text { that contribute } \\
\text { to local history. } \\
\text { Formulating } \\
\text { questions for } \\
\text { survey. }\end{array}$ & $\begin{array}{l}\text { Listing San } \\
\text { objects that } \\
\text { contribute to } \\
\text { their history. } \\
\text { Rescribing San } \\
\text { life-style and } \\
\text { practices from } \\
\text { pictures and } \\
\text { information. }\end{array}$ & $\begin{array}{l}\text { Written } \\
\text { descriptions } \\
\text { of early } \\
\text { settlements } \\
\text { and their } \\
\text { lifestyle and } \\
\text { livelihood. } \\
\text { Explanations } \\
\text { of how trade } \\
\text { advanced and } \\
\text { expanded. }\end{array}$ & $\begin{array}{l}\text { Descriptions } \\
\text { of life- } \\
\text { style and } \\
\text { location of } \\
\text { indigenous } \\
\text { inhabitants. } \\
\text { Explanations } \\
\text { for } \\
\text { colonisation } \\
\text { and clashes. }\end{array}$ & $\begin{array}{l}\text { Writing } \\
\text { definitions, } \\
\text { explanations, } \\
\text { providing reasons, } \\
\text { describing } \\
\text { background and } \\
\text { changes to the } \\
\text { economy. } \\
\text { Planning/writing } \\
\text { presentations. } \\
\text { Creating time- }\end{array}$ & $\begin{array}{l}\text { Essay writing } \\
\text { on background, } \\
\text { causes, results } \\
\text { and effects of } \\
\text { events. } \\
\text { leasons for }\end{array}$ \\
& & $\begin{array}{l}\text { Mind-mapping, } \\
\text { preparing } \\
\text { debates, } \\
\text { presenting } \\
\text { posters. }\end{array}$ \\
\end{tabular}

It appears that the second-order concept of multi-perspectivity is not well developed within this sample of textbooks, except in Grade 9. This is unfortunate, given that only about $20 \%$ of learners proceed to select history 
in Grade 10 (based on the figures from the 2013 National Diagnostic Report that 109046 wrote the Grade 12 history examinations in 2013 of a total of 56212 full time candidates). It means that the majority of South African learners who do not study history beyond Grade 9, are not developing a deep understanding of history as a discipline which requires one to see a range of perspectives.

\section{Conclusion}

The study concludes that one method of tracking progression of historical thinking in textbooks is by analysing the genre of texts. This study has showing that genres are effective in learners' structuring reading and writing demands, and thus developing historical thinking in textbooks. With regard to the structure of historical knowledge, progression is observed in substantive knowledge, where a shift from contextualised knowledge in Grade 3 and 4 to decontextualised knowledge can be seen across the seven textbooks. The analysis finds that the genre of texts that learners must read increases in complexity, starting with contextualised, local knowledge in Grades 3 and 4, and moving to more decontextualised knowledge in Grade 9. The study shows that the genre of the texts shifts from recording genres in the early grades to explaining, and then interpretation and argument in Grade 9.

In terms of writing demands, learners commence writing explanations and thus start engaging with the concept of cause and effect only in Grade 6. It is only at Grade 9 that learners are expected to engage with writing multiperspectives or to interpret and argue for a particular perspective as they are introduced to a range of different sources. Thus a genre analysis shows that there is some progression in the second order historical concepts but that multi-perspectivity is only engaged with in Grade 9. It seems that learners in Grade 3, 4 and 5 are hardly being inducted into the key concepts of history such as narrative, chronology and specific historical events.

\section{References}

Ashby, P \& Lee, P 2000. Progression in historical understanding among students ages 7-14. In: PN Stearns \& S Wineburg (eds.). Knowing, teaching and learning history. New York: New York Press. 
Bam, J \& Visser, P 1996. A sample chapter for a new history textbook. The Xhosa cattle killing. A new History for a new South Africa. Cape Town: Kagiso:154-195.

Bernstein, B 1971. On the classification and framing of educational knowledge. In: MFD Young (ed.). Knowledge and control: New directions for the sociology of education. London: Collier Macmillan:47-69.

Bernstein, B 1999. Vertical and horizontal discourse: An essay. British Journal of Sociology of Education, 20(2):157-173.

Bertram, C 2008a. Curriculum recontextualisation: A case study of the South African high school History curriculum. Unpublished Ph.D thesis. Pietermaritzburg: University of KwaZulu-Natal.

Bertram, C 2008b. "Doing History?” Assessment in history classrooms at a time of curriculum reform. Journal of Education, 45:155-177.

Bertram, C 2012. Exploring an historical gaze: A language of description for the practice of school history. Journal of Curriculum Studies, 43(3):429-442.

Bertram, C \& Bharath, P 2011. Specialised knowledge and everyday knowledge in old and new Grade 6 history textbooks. Education as Change, 15(1):63-80.

Bharath, P 2009. A study of knowledge representation in Grade 6 History textbooks before and after 1994. Unpublished M.Ed thesis. Pietermaritzburg: University of KwaZulu-Natal.

Chisholm, L 1981. Ideology, legitimation of the status quo and History textbooks in South Africa. Perspectives in Education, 3(5):134-151.

Chisholm, L 2005. The making of South Africa's National Curriculum Statement. Journal of Curriculum Studies, 37(2): 193-208.

Chisholm, L 2008. Migration, citizenship and South African History textbooks. South African Historical Journal, 60(3):352-374.

Chisholm, L 2013. The textbook saga and corruption in education. South African Review of Education, 19(1):7-22.

Coffin, C 2006a. Historical discourse. The language of time, cause and evaluation. London and New York: Continuum.

Coffin, C 2006b. Learning the language of school history: The role of linguistics in mapping the writing demands of the secondary school curriculum. Journal of Curriculum Studies, 38(4):413-429. 
Coffin, C 2006c. Mapping subject-specific literacies. NALDIC Quarterly, 3(3):13-26.

Coffin, C 2010. Language support in EAL contexts. Why systemic functional linguistics? (Special Issue of NALDIC Quarterly). NALDIC, Reading, UK.

Crawford, K 2003. The role and purpose of textbooks. International Journal of Historical Learning, Teaching and Research, 3(2):5-119.

Dean, E, Hartman, P \& Katzen, M 1983. History in black and white. An analysis of South African school history textbooks. Paris: UNESCO.

Dean, J 2004. Doing History: Theory, practice and pedagogy. In: S Jeppie (ed.). Toward new histories for South Africa: On the place of the past in our present. Cape Town: Juta Gariep.

Department of Education 2000. Report of the History/Archaeology panel to the minister of education. Ministry of education. Pretoria: Department of Education.

Department of Basic Education 2011. National Curriculum Statement Grades 4-6 Curriculum and Assessment Policy Statement. Home Language. Pretoria: Department of Basic Education.

Department of Basic Education 2011. National Curriculum Statement Grades 7-9 Curriculum and Assessment Policy Statement. Social Sciences. Pretoria: Department of Basic Education.

Department of Basic Education 2014. 2013 National Senior Certificate Examination. National diagnostic report. Pretoria: Department of Basic Education.

Derewianka, B 2003. Trends and issues in genre-based approaches. RELC Journal, 34(2):133154.

Derewianka, BM \& Jones, PT 2012. Teaching language in context. Melbourne: Oxford University Press.

Du Preez, JM, Du Preez, H \& Home, TJ 1983. African Afrikaner. Master symbols in South African school textbooks. Alberton: Librarius Felicitas.

Fang, Z \& Schleppegrell, MJ 2010. Disciplinary literacies across content areas: Supporting secondary reading through functional language analysis. Journal of Adolescent and Adult Literacy, 53(7):587-597.

Firth, BW 2013. "Powerful knowledge" in any textbook? An analysis of two South African History textbooks in pursuit of powerful knowledge. Unpublished M.Ed dissertation. Cape Town: University of Cape Town. 
Ford, A 2014. Progression in Historical thinking. An overview of key aspects of the mastery of historical thinking and practice. Available at http://scholar?hl=en\&q=Progr ession+in+historical+thinkingandallthat.co.uk. Accessed on 21 February 2015.

Friedman, M, Ranby, P \& Varga, E 2013. Solutions for all. Social Sciences. Learner's book. Grade 8. Gauteng: Macmillan.

Friedman, M, Ranby, P \& Varga, E 2013. Solutions for all. Social Sciences. Learner's book. Grade 9. Gauteng: Macmillan.

Kwang-Su, K 1999. The relationship between cultural identity and historical consciousness: a case study of history students at South African universities. Unpublished Ph.D thesis. Potchefstroom: Potchefstroom University for Christian Higher Education.

KwaZulu-Natal Department of Education 2000. Learning and teaching support material. Textbooks catalogue for 2014 academic year. General education and training (GET): Grades 1-7.

LaSpina, JA 1998. The visual turn and the transformation of the textbook. Lawrence Erlbaum Associates: London.

Lee, P \& Shemilt, D 2003. A scaffold not a cage: Progression and progression models in history. Teaching History, 113:13-23.

Lee, P \& Ashby, R 2001. Progression in historical understanding. In: P Seixas, P Stearns \& S Wineburg (eds.). Teaching, knowing and learning History. New York: University Press.

Lévesque, S 2008. Thinking historically: Educating students for the twenty-first century. Toronto: University of Toronto Press Incorporated.

Maposa, MT 2014. An analysis of the construction of African Consciousness in contemporary South African History textbooks. Unpublished Ph.D thesis. Pinetown: University of KwaZulu-Natal.

Martin, JR 2013. Embedded literacy: Knowledge as meaning. Linguistics and Education, 24:23-37.

Matoti, SM 1990. An analysis of some school history textbooks with special reference to styles of concept representation. Unpublished M.Ed. dissertation. Grahamstown: Rhodes University.

Mazabow, G 2003. The development of historical consciousness in the teaching of History in South African schools. Unpublished Ph.D thesis. Pretoria: University of South Africa. 
Minte, AR 2014. Recent historiographical work on Chilean History textbooks. Eckert Beitrage, 1. Available at www.edumeres.net/urn/urn:nbn:de:0220-2014-00157. Accessed on 21 February 2015.

Moore, R 2004. Education and society. Issues and explanations in the sociology of education. United Kingdom: Polity Press.

Muller, J 2004. Differentiation and progression in the FETC. In: M Young \& J Gamble (eds.). Knowledge, curriculum and qualifications for South African further education. Cape Town: HSRC Press.

Ranby, P \& Zimmerman, A 2012. Solutions for all. Social Sciences. Learner's book. Grade 4. Gauteng: Macmillan.

Ranby, P \& Zimmerman, A 2012. Solutions for all. Social Sciences. Learner's book. Grade 5. Gauteng: Macmillan.

Ranby, P \& Zimmerman, A 2012. Solutions for all Social Sciences. Learner's book. Grade 6. Gauteng: Macmillan.

Ranby, P \& Varga, E 2013. Solutions for all. Social Sciences. Learner's book. Grade 7. Gauteng: Macmillan.

Ranchod, KBD 2001. The accessibility of the language used in the Grade 9 History textbook. Unpublished M.Ed dissertation. Faculty of Education: Vista University.

Romero, N 2014. Teaching practises. Use of printed textbooks in Argentinian elementary schools. Eckert Beitrage, 2. Available at www.edumeres.net/ urn:nbn:de:0220-2014-00220. Accessed on 15 February 2015.

Schleppegrell, MJ, Greer, S \& Taylor, S 2008. Literacy in history: Language and meaning. Australian Journal of Language and Literacy, 31(2):174-187.

Schleppegrell, MJ 2012. Systemic functional linguistics: Exploring meaning in language. In: JP Gee \& M Handford (eds.). The Routledge Handbook of Discourse Analysis. New York: Routledge.

Schleppegrell, MJ, Achugar, M \& Oteiza T 2012. The grammar of History: Enhancing content-based instruction through a functional focus on language. Tesol Quarterly, 32(1):67-93.

Seixas, P 1999. Beyond 'content' and 'pedagogy': In search of a way to talk about history education. Journal of Curriculum Studies, 31(3):317-337.

Seixas, P 2006. Benchmarks of Historical thinking. A framework for assessment in Canada. Centre for the Study of Historical Consciousness: UBC. 
Seleti, Y 1997. From History to Human and Social Sciences. The New Curriculum Framework and the end of History for the General Education and Training Level. Durban: University of KwaZulu-Natal.

Shemilt, D 1980. History 13-16, Evaluation study. Edinburgh: Homes McDougall.

Van Beek, U 2000. Youth in the new South Africa: A study of historical consciousness. Polish Sociological Review, 131:339-354.

Van Drie, J \& Van Boxtel, C 2008. Historical reasoning: Towards a framework for analysing students' reasoning about the past. Education Psychology Revolutions, 20:87-110.

Van Eeden, ES 2008. Impressions on aspects of the process - and outcomes - of curriculum transformation in History for schools after 1994 in South Africa. New Contree, 56:105-140.

Van Jaarsveld, FA 1989. Historical consciousness and the reinterpretation of history. Kwa Dlangezwa: University of Zululand.

Waller, BJ 2009. How does historical literacy manifest itself in South African grade 10 history textbooks? Unpublished M.Ed dissertation. Pinetown: University of KwaZuluNatal.

Wassermann, JM 2008. The historical consciousness of Afrikaner adolescents. A small scale survey. Historical consciousness - historical culture. International Society for History Didactics 2006/7 Yearbook. Schwalbach: Wochenschauverlag. 